\title{
TEMPERATURE EFFECTS IN UP-CONVERSION PROCESSES OF ERBIUM - YTTERBIUM DOPED OXYFLUORIDE SILICATE GLASS
}

\author{
J. Grube, A. Sarakovskis, L. Dimitrocenko. M. Springis \\ Institute of Solid State Physics, University of Latvia, \\ 8 Kengaraga Str., Riga, LV-1063, LATVIA \\ e-mail: jurgis.grube@cfi.lu.lv
}

\begin{abstract}
$\mathrm{Er}^{3+}-\mathrm{Yb}^{3+}$ doped oxyfluoride glass has been synthesized and investigated. It was found that the up-conversion spectrum of the sample excited by a $980 \mathrm{~nm}$ laser diode is highly dependent on the temperature of the sample. Using fluorescence intensity ratio technique the green up-conversion emissions at $525 \mathrm{~nm}$ and $550 \mathrm{~nm}$ were studied in detail in the temperature range $120-600 \mathrm{~K}$. The potential applicability of the obtained results in the field of the temperature sensing is discussed.
\end{abstract}

\section{INTRODUCTION}

For many years rare-earth (RE) doped materials have been playing an outstanding role in many applications. Owing to their abundant energy level structure, many fields of science and technology - like solid-state lasers, color displays, optical telecommunication, etc.- employ the unique properties of these materials [1-3]. In the past years much attention has been paid to the studies of up-conversion (UC) processes in the RE-doped phosphors related to the emission of higher-energy photons (visible and UV) when excited by lower-energy photons (usually IR) [4]. The UC process could be used in a wide range of applications like white light simulation [5], improvement of solar battery efficiency [6], high temperature sensors [7], and others.

Among other RE dopants, erbium trivalent ions have been used and studied most widely due to their particular spectroscopic properties: the main UC luminescence excitation bands $(800 \mathrm{~nm}, 980 \mathrm{~nm}$ and $1500 \mathrm{~nm})$ lie in the wavelength region efficiently covered by the solid-state and semiconductor laser products, while the luminescence bands are positioned in the visible and near-ultraviolet spectral regions. $\mathrm{Yb}^{3+}$ ions are often used in combination with erbium or other RE dopants due to their large absorption cross-section at $980 \mathrm{~nm}$ and the efficient energy transfer.

In the present research we will focus our attention on the preparation of oxyfluoride glass doped with $\mathrm{Er}^{3+}$ and $\mathrm{Yb}^{3+}$ ions and on the studies of UC properties of the glass at different temperatures.

\section{EXPERIMENTAL}

Erbium-doped silicate glass was prepared at the Institute of Solid State Physics, University of Latvia. For the glass synthesis, $50 \mathrm{~mol} \% \mathrm{SiO}_{2}(99.99 \%), 25 \mathrm{~mol} \%$ $\mathrm{Li}_{2} \mathrm{CO}_{3}$ (99.99\%), $20 \mathrm{~mol} \% \mathrm{YF}_{3}(99.999 \%), 3 \mathrm{~mol} \% \mathrm{YbF}_{3}(99.999 \%)$ and $2 \mathrm{~mol} \%$ 
$\mathrm{ErF}_{3}(99.999 \%)$ powders were used. The powders were homogenized and the mixture was melted in a corundum crucible at $1200^{\circ} \mathrm{C}$ in the air. After 1 hour the glass was poured into a cupper mold and cooled to room temperature. Afterwards the obtained glass sample was cut $(5 \times 5 \times 1 \mathrm{~mm})$ and polished. For the spectral measurements at different temperatures the sample was mounted on the cold-finger of a liquid nitrogen cryostat. UC luminescence was excited by a temperature-controlled laser diode from Thorlabs with radiant power up to $1 \mathrm{~W}$ of CW radiation at $980 \mathrm{~nm}$. Luminescence spectra were recorded using a Czerny-Turner type monochromator equipped with a photomultiplier tube H8259-01. The temperature of the sample during the spectral measurements was controlled at a precision of $1 \mathrm{~K}$ by ironconstantan thermocouple set to the front side of the sample.

\section{RESULTS AND DISCUSSION}

The UC luminescence spectrum of the glass sample excited by a $980 \mathrm{~nm}$ laser diode is shown in Fig. 1. The bands around $525 \mathrm{~nm}, 550 \mathrm{~nm}$ and $650 \mathrm{~nm}$ are the characteristic emissions of $\mathrm{Er}^{3+}$ ions related to the electron transitions from levels ${ }^{2} \mathrm{H}_{11 / 2},{ }^{4} \mathrm{~S}_{3 / 2}$ and ${ }^{4} \mathrm{~F}_{9 / 2}$, respectively, to the ground state ${ }^{4} \mathrm{I}_{15 / 2}[8]$.

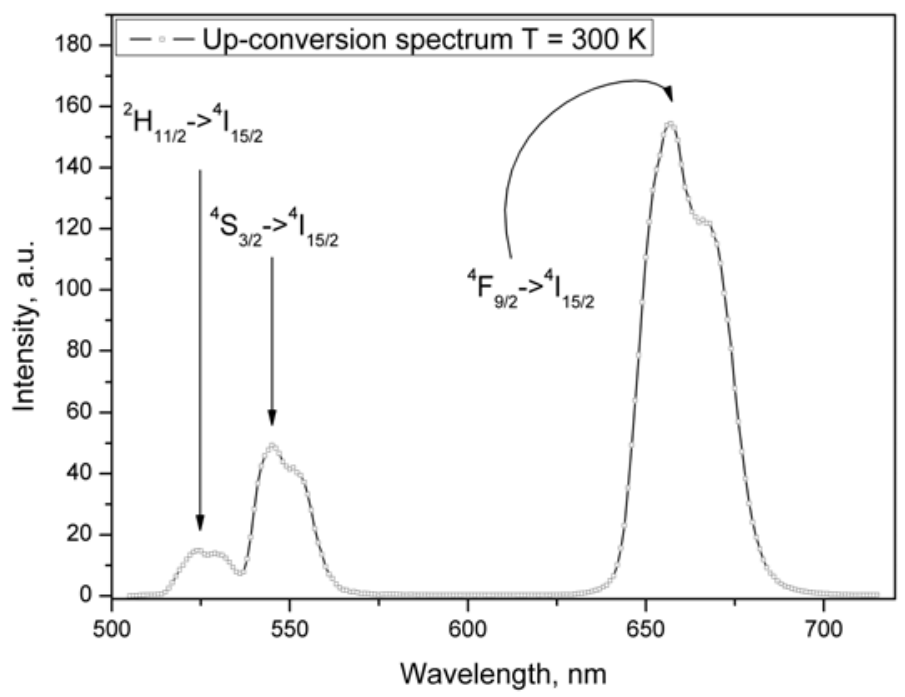

Fig. 1. UC luminescence spectrum excited at $980 \mathrm{~nm}$ measured at $300 \mathrm{~K}$.

The energy scheme of $\mathrm{Yb}^{3+}-\mathrm{Er}^{3+}$ system and the main mechanisms of the excitation, along with the up-conversion emission transitions, are shown in Fig. 2. As can be seen in the diagram, ${ }^{4} \mathrm{~F}_{7 / 2}$ level of $\mathrm{Er}^{3+}$ ion can be populated by different routes:

1. Sequential absorption of two $980 \mathrm{~nm}$ photons: ${ }^{4} \mathrm{I}_{15 / 2}+$ IR photon $\rightarrow{ }^{4} \mathrm{I}_{11 / 2}$ (ground state absorption - GSA) followed by ${ }^{4} \mathrm{I}_{11 / 2}+\mathrm{IR}$ photon $\rightarrow{ }^{4} \mathrm{~F}_{7 / 2}$ (excited state absorption - ESA).

2. Cross relaxation process (CR) between $\mathrm{Er}^{3+}$ ions: ${ }^{4} \mathrm{I}_{11 / 2}+\left[{ }^{4} \mathrm{I}_{11 / 2} \rightarrow{ }^{4} \mathrm{I}_{15 / 2}\right] \rightarrow$ $\rightarrow{ }^{4} \mathrm{~F}_{7 / 2}$.

3. Energy transfer processes (ET) involving $\mathrm{Yb}^{3+}$ ion: ${ }^{4} \mathrm{I}_{15 / 2}+\left[{ }^{2} \mathrm{~F}_{5 / 2}\left(\mathrm{Yb}^{3+}\right) \rightarrow\right.$ $\left.\rightarrow{ }^{2} \mathrm{~F}_{7 / 2}\left(\mathrm{Yb}^{3+}\right)\right] \rightarrow{ }^{4} \mathrm{I}_{11 / 2},{ }^{4} \mathrm{I}_{11 / 2}+\left[{ }^{2} \mathrm{~F}_{5 / 2}\left(\mathrm{Yb}^{3+}\right) \rightarrow{ }^{2} \mathrm{~F}_{7 / 2}\left(\mathrm{Yb}^{3+}\right)\right] \rightarrow{ }^{4} \mathrm{~F}_{7 / 2}$. 
Afterwards, the non-radiative decays to ${ }^{2} \mathrm{H}_{11 / 2},{ }^{4} \mathrm{~S}_{3 / 2}$ and ${ }^{4} \mathrm{~F}_{9 / 2}$ levels took place followed by radiative transitions from the levels to the ground state ${ }^{4} \mathrm{I}_{15 / 2}$, giving rise to the green and the red luminescence bands.

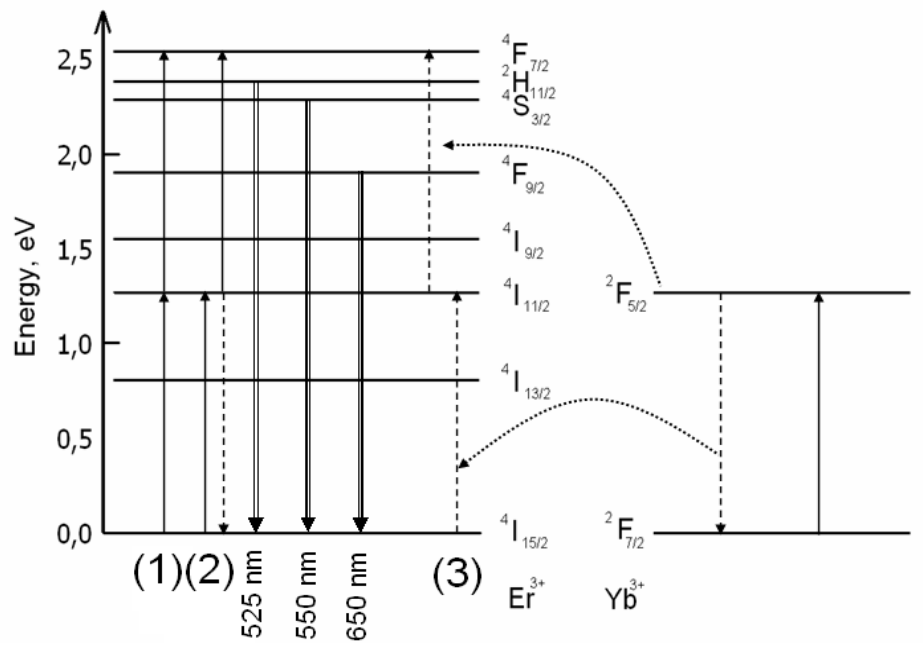

Fig. 2. The energy scheme for optical transitions in $\mathrm{Yb}^{3+}-\mathrm{Er}^{3+}$ system excited by $980 \mathrm{~nm}[9]$.

A very important feature of the UC process is the specific dependence of the luminescence intensity on the excitation power: $I=P^{n}$, where $n$ is the number of photons required to populate the emitting levels [10]. In the log-log plot the slope of the curve gives the number of photons involved in the excitation of the UC. This dependence measured for the two green bands at $525 \mathrm{~nm}$ and $550 \mathrm{~nm}$ is presented in Fig. 3. It can be seen in the figure that the absorption of two IR photons is required to populate ${ }^{2} \mathrm{H}_{11 / 2}$ and ${ }^{4} \mathrm{~S}_{3 / 2}$ levels.

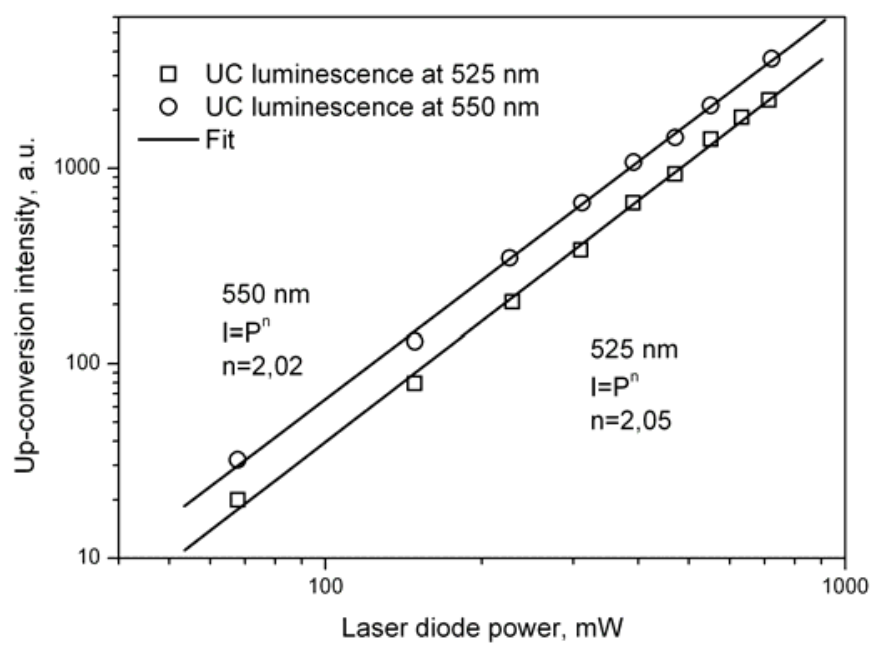

Fig. 3. UC luminescence intensity dependence on excitation power at $980 \mathrm{~nm}$ measured at $300 \mathrm{~K}$. 
It should also be noted that ${ }^{2} \mathrm{H}_{1 / 2}$ and ${ }^{4} \mathrm{~S}_{3 / 2}$ levels in an $\mathrm{Er}^{3+}$ ion are thermally coupled: level ${ }^{2} \mathrm{H}_{11 / 2}$ could be populated via thermal excitation from ${ }^{4} \mathrm{~S}_{3 / 2}$ level. Since the non-radiative relaxation from ${ }^{4} \mathrm{~S}_{3 / 2}$ to the nearest lower lying level ${ }^{4} \mathrm{~F}_{9 / 2}$ requires emission of three phonons (the difference between the energy levels about $3300 \mathrm{~cm}^{-1}$ [8] but the characteristic phonon energy of silicate glass $\sim 1100 \mathrm{~cm}^{-1}$ [11]) while only one phonon is required to bridge the energy gap between ${ }^{2} \mathrm{H}_{11 / 2}$ and ${ }^{4} \mathrm{~S}_{3 / 2}$ (about $1000 \mathrm{~cm}^{-1}$ ), one can treat the system being in a thermal quasiequilibrium state. In this case, the relative population of the two thermally coupled levels and the corresponding intensities of the UC luminescence emissions follow the well-known Boltzmann distribution:

$$
R=\frac{N_{2} \mathrm{H}_{11 / 2}}{N_{{ }^{4} \mathrm{~S}_{3 / 2}}}=\frac{\mathrm{I}_{525}}{\mathrm{I}_{550}}=\frac{A_{1} h v_{1}}{A_{2} h v_{2}} e^{--\frac{\Delta E}{k T}}=C e^{-\frac{\Delta E}{k T}},
$$

where $A_{1}, A_{2}$ are the total transition probabilities from the corresponding levels to the ground state,

$v_{1}, v_{2}$ are the light emission frequencies,

$\Delta E \quad$ is the energy gap between two emitting levels, and

$C$ is a constant.

This effect was proposed as a method (fluorescence intensity ratio (FIR)) for temperature sensing $[12,13]$. In the frames of this method the ratio of two measured intensities corresponding to the transitions from the thermally coupled excited levels to the ground state defines the temperature of the sensor.

The UC luminescence spectra of the oxyfluoride glass excited by $980 \mathrm{~nm}$ measured at $120 \mathrm{~K}, 300 \mathrm{~K}$ and $600 \mathrm{~K}$ are presented in Fig. 4. Indeed, it can be seen that the intensities of the green emissions at $525 \mathrm{~nm}$ and $550 \mathrm{~nm}$ change when the temperature of the sample is varied, while the spectral position of the bands remains unchanged. For the analysis of the FIR dependence on the temperature of the sample the spectrum of green emission was split into two parts $(520-530 \mathrm{~nm}$ and $545-555 \mathrm{~nm}$ ) and the intensity distributions in the two split bands were integrated. Afterwards two integrated intensities $\mathrm{I}_{525}$ and $\mathrm{I}_{550}$ were divided and the ratio $R=\mathrm{I}_{525} / \mathrm{I}_{550}$ at a certain temperature was obtained. Then the temperature of the sample was changed and the calculation of the ratio of the integrated intensities was repeated. It is worth mentioning that the ratio of the integrated intensities calculated in such a manner simulates the use of commercially available bandpass interference filters which select the appropriate spectral regions from the whole UC luminescence spectrum of the sample corresponding to transitions ${ }^{2} \mathrm{H}_{11 / 2} \rightarrow{ }^{4} \mathrm{I}_{15 / 2}$ and ${ }^{4} \mathrm{~S}_{3 / 2} \rightarrow{ }^{4} \mathrm{I}_{15 / 2}$.

The FIR dependence on the temperature of the sample is shown in Fig. 5. It can be seen that the measured intensity ratio closely follows the exponential dependence predicted by the Boltzmann distribution (Eq. (1)). The fit by the exponential function yields the coefficients $a=6.2$ and $b=\frac{\Delta E}{k}=1013$. From $b$ one can easily calculate that $\Delta E=0.09 \mathrm{eV}$, which is in a good accordance with the spectral distance between the two green bands in the UC luminescence spectrum (Fig. 4). 


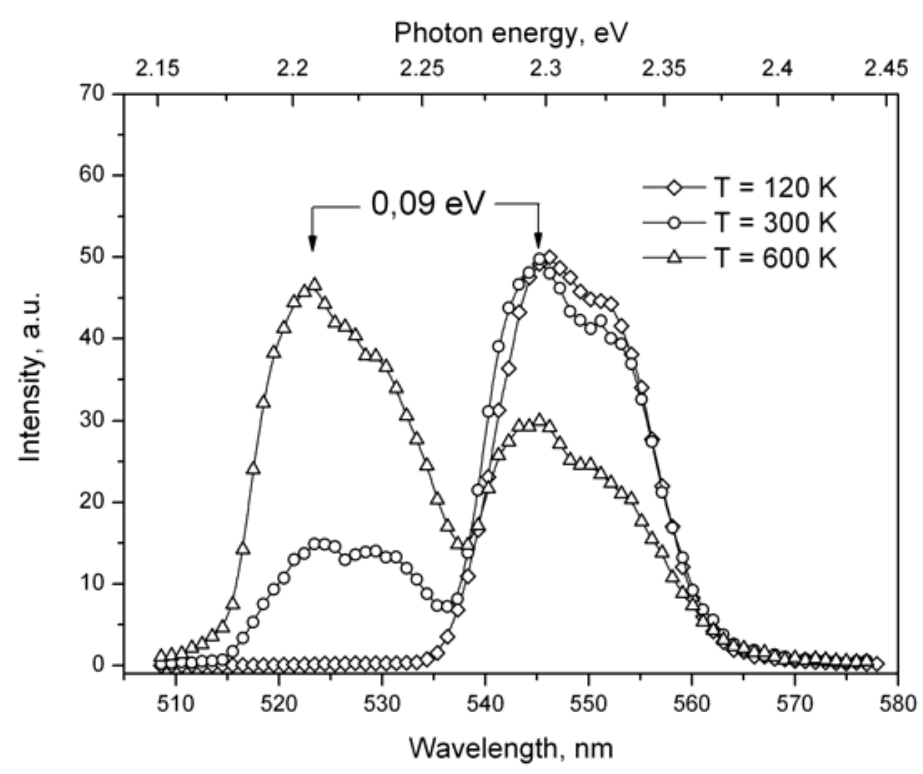

Fig. 4. Up-conversion spectra excited by $980 \mathrm{~nm}$ measured at $300 \mathrm{~K}$ (closed circles) and at $625 \mathrm{~K}$ (open circles).

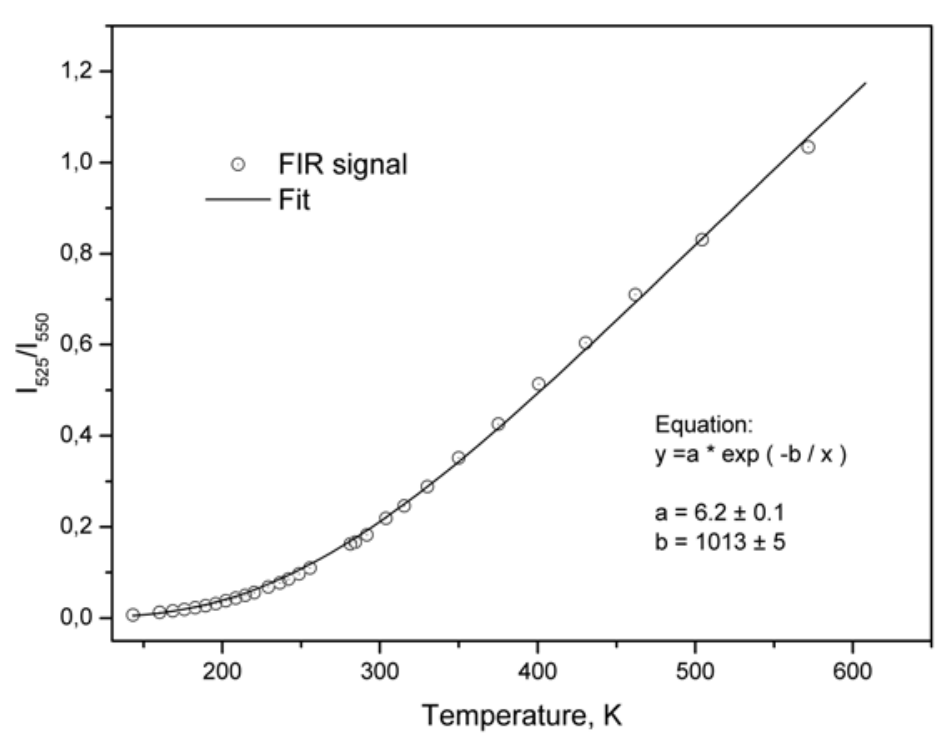

Fig. 5. UC luminescence intensity ratio $\mathrm{I}_{525} / \mathrm{I}_{550}$ dependence on temperature excited by $980 \mathrm{~nm}$.

For the practical purposes in the field of temperature sensing an important issue one has to think about is the sensitivity of the temperature sensor. The sensitivity can be defined as

$$
S=\frac{d R}{d T}=R \frac{\Delta E}{k T^{2}},
$$

where $R$ is the ratio of the intensities in Eq. (1) [14]. 
From Fig. 6 it can be seen that the sensitivity reaches the maximum value of $3.2 \times 10^{-3} \mathrm{~K}^{-1}$ at the temperature $T=500 \mathrm{~K}$ and drops down to $2.5 \times 10^{-4} \mathrm{~K}^{-1}$ at $150 \mathrm{~K}$.

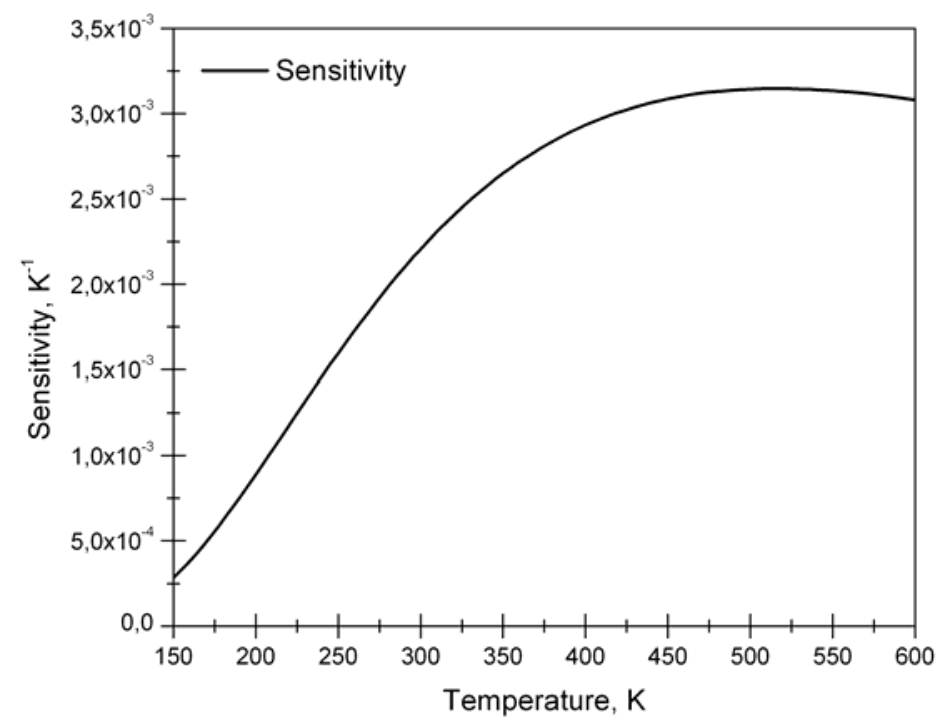

Fig. 6. The sensor sensitivity curve $S=d R / d T$.

To compare the obtained results with those measured for other host materials, the maximum sensitivity values and the operating temperature regions for different hosts are summarized in Table 1.

\section{Maximum sensitivity and working temperature regions for hosts containing $\mathrm{Er}^{3+}$ ions}

Table 1

\begin{tabular}{|c|c|c|c|}
\hline Host material & $\begin{array}{c}\text { Temperature } \\
\text { region, } \\
\mathrm{K}\end{array}$ & $\begin{array}{c}\text { Sensitivity, } \\
\mathrm{K}^{-1}\end{array}$ & Reference \\
\hline $\begin{array}{c}\text { Fluoroindate glass: } \\
\mathrm{Er}^{3+}\end{array}$ & $300-448$ & 0.0040 & {$[14]$} \\
\hline $\begin{array}{c}\text { Chalcogenide glass: } \\
\mathrm{Yb}^{3+}-\mathrm{Er}^{3+}\end{array}$ & $293-523$ & 0.0052 & {$[14]$} \\
\hline $\begin{array}{c}\text { Silicate glass: } \\
\mathrm{Yb}^{3+}-\mathrm{Er}^{3+}\end{array}$ & $296-723$ & 0.0033 & {$[14]$} \\
\hline $\begin{array}{c}\text { Oxyfluoride silicate glass: } \\
\mathrm{Yb}^{3+}-\mathrm{Er}^{3+}\end{array}$ & $150-600$ & 0.0032 & $\begin{array}{c}\text { Current } \\
\text { research }\end{array}$ \\
\hline
\end{tabular}

The measurements conducted for the oxyfluoride glass show that the maximum sensitivity for the sample is comparable with that obtained by Li et al. [14]. The sensitivity values for fluoroindate and chalcogenide glasses are higher compared with our sample but for all the glasses operating temperature regions are narrower compared with our sample. Unfortunately, we were unable to register a FIR signal at the temperatures higher than $600 \mathrm{~K}$ due to the experimental setup 
restrictions. Nevertheless we believe that the upper temperature limit lies higher than the measured $600 \mathrm{~K}$. In the low temperature region of 120-140 K no credible signal in the UC luminescence spectrum at $525 \mathrm{~K}$ could be measured due to the low thermal excitation rate of ${ }^{2} \mathrm{H}_{11 / 2}$ from ${ }^{4} \mathrm{~S}_{3 / 2}$ (Fig. 4). The detectable FIR signal was observed starting from $150 \mathrm{~K}$ making this temperature the bottom limit of the sensor operation.

\section{CONCLUSIONS}

The $\mathrm{Yb}^{3+}-\mathrm{Er}^{3+}$ doped oxyfluoride silicate glass has been prepared. Strong emission bands centred at about $525 \mathrm{~nm}\left({ }^{2} \mathrm{H}_{11 / 2} \rightarrow{ }^{4} \mathrm{I}_{15 / 2}\right)$ and $550 \mathrm{~nm}\left({ }^{4} \mathrm{~S}_{3 / 2} \rightarrow{ }^{4} \mathrm{I}_{15 / 2}\right)$ were detected in the UC luminescence spectrum of the sample when excited by a $980 \mathrm{~nm}$ laser diode. The FIR technique was applied to study the possibility of temperature sensing by the sample. It was found that FIR signal changes when the temperature is varied in the range from $150 \mathrm{~K}$ to $600 \mathrm{~K}$. This makes the material a promising candidate in the field of the temperature sensing by optical means.

\section{AKNOWLEDGEMENTS}

This work was supported by the National Research Programme in Material Science, Government of Latvia. Financial support of European Social Fund (ESF) is greatly appreciated.

\section{REFERENCES}

1. Mendez-Ramos, J., Tikhomirov, V.K., Rodriguez, V.D., \& Furniss, D. (2007). J. of Alloys and Compounds, 440 (1-2), 328.

2. Schweizer, T., Hewak, D.W., Payne, D.N., Jensen, T., \& Huber, G. (1996). El. Lett., 32 (7), 666.

3. Payne, D.N., \& Reekie, L. (1988). Opt. Commun. 49 (1).

4. Auzel, F. (2004). Chem. Rev., 104, 139.

5. Silva, J.E.C., de Sa, G.F., \& Santa-Cruz, P.A.J. (2001). J. of Alloys and Compounds, 323-324, 260.

6. Shalav, A., Richards, B.S., \& Green, M.A. (2007). Solar Energy Materials and Solar Cells, 91, 829.

7. Dong, B., Yang, T., \& Lei, M.K. (2007). Sensors and Actuators, B 123, 667.

8. Foldvari, I., Beregi, E., Munoz, A., Sosa, F.R., \& Horvath, V. (2002). Opt. Mat., 19, 241.

9. Liang, H., Yang, K., Zhang, X., Machida, K., \& Meng, J. (2006). J. of Alloys and Compounds, 408-412, 835.

10. Polnau, M., Gamelin, D.R., Luthi, S.R., Gudel, H.U., \& Hehlen, M.P. (2000). Phys. Rev. $B 61$ (5), 3337.

11. Dejneka, J.M. (1998). MRS Bull., 23, 57.

12. de Camarago, A.S.S., Possatto, J.F., de O. Nunes, L.A., Botero, E.R., Andreeta, M., Garcia, D., \& Eiras, J.A. (2006). Sol. St. Commun., 137, 1-5.

13. Kusama, H., Sovers, O. J. \& Yoshioka, T. (1976). Jpn. J. of Appl. Phys., 15, 2349.

14. Li, C., Dong, B., Li, S., \& Song, C. (2007). Chem. Phys. Lett., 443, 426. 
TEMPERATŪRAS EFEKTI DAUDZFOTONU IEROSMES PROCESĀ

AR ERBIJU UN ITERBIJU LEĢĒTĀ

OKSIFLUORĪDU SILIKĀTA STIKLĀ

J. Grūbe, A. Sarakovskis, L. Dimitročenko, M. Spriņgíis

S u m m a r y

Tika sintezēts un pētīts ar $\mathrm{Er}^{3+}$ un $\mathrm{Yb}^{3+}$ legéts oksifluorīda stikls. Ierosinot paraugu daudzfotonu procesā ar $980 \mathrm{~nm}$ starojumu, novērota luminiscences spektra būtiska atkarība no temperatūras, intervālā 120-600 K. Izmantojot luminiscences intensitāšu attiecības metodi, spriests par iespējamo oksifluorīda stikla pielietojumu temperatūras sensoru jomā.

17.10.2008. 